\title{
The Effect of Acceleration on Subsequent Course Success Rates Based on the North Carolina Developmental Mathematics Redesign
}

\author{
Tammy J. Bishop, Wayne Community College \\ Nara Martirosyan, Sam Houston State University \\ D. Patrick Saxon, Sam Houston State University
}

Forrest Lane, Sam Houston State University

\section{ABSTRACT}

Recent trends in developmental education (DE) include the reduction of time spent in DE courses, which includes the acceleration of the course content. In 2011, the North Carolina Community College System redesigned all DE mathematics courses using this trend of acceleration. This study looks at the subsequent gateway mathematics course success rates for students who took the course in the traditional 16-week semester format and in the new 4-week accelerated modular format. The results of this study showed that there was no difference in the success rates of the two formats. The researchers concluded that acceleration of courses does not affect the subsequent course success rates.

n 2011, the North Carolina Community College System (NCCCS) redesigned the DE mathematics curriculum from three 16 -week courses (48 weeks) into eight 4-week courses (32 weeks), based on mastery (NCCCS, 2013). This reduction was done so that the entire sequence could be completed in one year (NCCCS, 2011b). Different time frames for accelerated courses were evaluated and it was determined that the 4-week model worked best in designing accelerated courses (Austin \& Gustafson, 2006). Overlap of redundant course material was eliminated and multiple points of successfully exiting DE were established, based upon the credit-bearing, college-level course that was needed for a program of study (NCCCS, 2011b). Each 4-week course was graded on a mastery system of $80 \%$. Students that did not meet the $80 \%$ mastery requirement were immediately re-enrolled in the same module for the next four weeks. Hence, students were not getting slowed down in repeating long courses, but instead immediately repeating the 4-week course they did not master. The shortened class lengths allowed students to repeat courses in the same semester, rather than waiting 16-weeks to repeat a course. Students needing three 4-week mathematics modules could repeat one module and still finish in one semester. Consequently, students were able to move on to college-level, credit-bearing courses more quickly.

The acceleration of the sequence leads to discussions of the effect of acceleration on the retention of material. Jaggars and Hodara (2011) questioned whether acceleration of DE mathematics courses hinders student progression and learning. Edgecombe (2011) discussed the benefits of accelerating the sequence, which included less time, greater persistence, increased retention of knowledge, and the creation of an environment of rigor needed in the subsequent courses. The shortened course length allowed students to study and master one topic at a time, shortening the time for forgetting mathematics concepts in between courses (Edgecombe, 2011).

One purpose of the NCCCS redesign of DE coursework was to increase the subsequent course pass-rate for DE students completing a credit-bearing gateway course. It is essential to evaluate the success of students in subsequent courses in order to determine the effectiveness of the new structure and acceleration, which may have value for other institutions exploring accelerated course-design options. Therefore, the purpose of this study was to evaluate the effectiveness of the NCCCS redesign in improving subsequent gateway course success rates among students who took the accelerated 4-week DE mathematics courses versus the prior 16 -week courses. Twelve community colleges from the North Carolina system were chosen to participate in this study.

\section{Literature Review}

The NCCCS redesign reduced the calendar time needed to complete a DE mathematics sequence (NCCCS, 2013). Edgecombe (2011) defines acceleration "as the reorganization of instruction and curricula in ways that facilitate the completion of educational requirements in an expedited manner" (p. 4). North 
Carolina's design incorporated principles of curricular redesign used in the California Acceleration Project (CAP) to reduce the amount of time students spent in the classroom, sometimes referred to as seat-time (Haywood \& Willett, 2014). In addition to shortening the amount of time to complete DE mathematics courses, this curricular redesign also refined the curriculum to include only material needed to be successful in the gateway course (Edgecombe, 2011). Accelerated courses are intentionally more demanding than a traditional semester course, not only because of increased workload, but because the expectations of the course are more in line with the outcomes of the gateway course (Baragan \& Cormier, 2013; CCRC, 2012; Edgecombe, 2011; Haywood \& Willett, 2014; Jaggars, Edgecombe, \& Stacey, 2014; Nodine, Dadgar, Venezia, \& Bracco, 2013). Due to this increased demand in the new course design, deeper understanding of a concept is possible in an accelerated course because of the expectation to think through solutions and situations (Stigler, Givvin, \& Thompson, 2010).

Modularization of content accelerated the $D E$ sequence in the NCCCS redesign. Concepts were broken into individual units of study (NCCCS, 2011a), requiring $80 \%$ mastery to be obtained for all topics needed to succeed in the subsequent gateway course (McTiernan, Palmer, \& Fulton, 2013). Prerequisites for gateway courses were customized (Edgecombe, 2011), and students exited the sequence once they had mastered the topics required for their program of study.

Mastery of content to $80 \%$ or higher was integral to the NCCCS redesign (NCCCS, 2011b). Benjamin Bloom first introduced mastery learning in 1968 as instructional units taught in a time of approximately one to two weeks, followed by an initial assessment, a review of the weak topics, and a final assessment (Guskey, 2001). Since acceleration increased rigor in the classroom, requiring mastery facilitated the possibility that students would understand the material required and remember it in the subsequent course once they moved on (Guskey, 2001). Mastery promoted a deeper level of understanding of the material and provided a deeper foundation for future courses as students progressed through the mathematics sequence (Ariovich \& Walker, 2014). Since, mathematics is a subject that builds upon prior knowledge, subsequent mathematics success is almost impossible without initial success and mastery of foundational content (Boylan, 2011).

\section{Related Research}

Two colleges using acceleration were studied for their effect on student success. The first one featured The Community College of Denver, where the FastStart program was designed and implemented for lower-scoring students by accelerating the sequence using compression (Jaggars, Hodara, Cho \& Xu, 2014). In the spring of 2006, the Community College of Denver compressed its three-semester mathematics sequence (three 16-week courses) into two semesters (Jaggars, Hodara et al., 2014). Students had the choice of taking the two lowest levels in an 8-week format and the highest level the next semester in 16 weeks or vice versa. Seat-time was not reduced, just longer blocks of time were required, which provided the opportunity for instructors to "implement a wider variety of instructional activities" (Jaggars, Hodara et al., 2014, p. 6). The study investigated the likelihood of accelerated students completing the college-level gateway course and their success. The sample was taken from courses between spring 2006 and spring 2008 and resulted in a sample size of 133 in the program group and 1,222 in the comparison group. The results of propensity score matching showed that FastStart students were $11 \%$ more likely to complete gateway courses than those in the traditional sequence, and once enrolled in the gateway course, those students performed just as well as those who did not take the accelerated courses (Jaggers, Hodara et al., 2014). Researchers concluded that accelerated courses provide "students with a strong positive boost in terms of their probability of enrolling in and completing college-level math" (Jaggers, Hodara et al., 2014, p. 18).

In fall 2009, Queensborough

Community College (QCC) in Bayside, New York, tried an accelerated DE arithmetic class, but unlike The Community College of Denver, they used curricular redesign, which reduced the seattime required (Guy, Cornick, Holt, \& Russell, 2015). The college also left all the other courses in the DE mathematics sequence the same. The original course was not eliminated, so students had a choice between the new accelerated 4-week, 20-hour student-centered Arithmetic course, or the original 16week teacher-centered course. The traditional lecture format was replaced with active engagement in problem solving activities to encourage cooperative learning (Guy et al., 2015). Guy et al. (2015) limited their participants based on four pre-determined criteria (i.e., COMPASS taken before taking a mathematics course, COMPASS score greater than or equal to 25 and less than 30 , if an arithmetic course was 
the first mathematics course taken, and if a student's first attempt at the course was Fall 2009 - Fall 2012), resulting in a sample size of 1,001 students.

Using Fisher's exact (an association's test), statistically significant results in favor of the accelerated courses were obtained in the following categories: passing the course the first time, passing the course any time during the semester, enrolling in the subsequent course, and completing the sequence (Guy et al., 2015). The results of this study were both positive and negative. Out of the 1,001 students taking arithmetic through fall 2012, 233 chose the traditional 16-week format and 768 chose the accelerated 4-week format. Of those students, $618(80 \%)$ passed the accelerated course sometime between fall 2009 and 2012, while only 159 (68\%) passed the traditional course in the same amount of time. A total of $676(68 \%)$ students enrolled in the next course, Elementary Algebra; 144 (62\%) were from the traditional course and 532 (69\%) were from the accelerated course. Results for completing the next course in the sequence the next semester, however, were weak. In fall 2011, 959 students enrolled in the accelerated arithmetic course, but only 107 (11\%) of those successfully completed the Elementary Algebra course spring 2012. Guy et al. (2015) noted that there were several flaws in the study (e.g., did not begin as a research study, students self-selected courses, significant differences in sample size), and that "generalizability of these results may be limited" (p. 8), so it is difficult to determine what part of the redesign was most effective. Guy et al. (2015) also stated that "the entire sequence should be viewed as the redesign target" (p. 9) and the accelerated format gave "students a lower cost, less time-consuming option to persist" (p. 9).

As accelerations becomes more and more common as a redesign strategy for DE courses, additional research could add to the body of literature that exists. Acceleration design is still in its infancy of implementation; so much of the research is limited to a few programs with only a couple of years of implementation. Comparative research over a longer time frame will help establish the long-term effects of acceleration and success.

\section{Method}

A non-experimental, descriptive research design (Johnson \& Christensen, 2012) answered the following research question: What is the difference in subsequent-course pass rates (students making a $C$ or better) in gateway mathematics courses for former DE mathematics students based on the type of DE mathematics course completed (4-week versus 16-week)? This research describes the subsequent-course success rates of the present 4-week DE mathematics courses compared to the subsequent course-success rates of the past 16-week courses.
Data were gathered from a year prior to the redesign (2010-11) and a year immediately after the implementation of the redesign (2013-14). The dependent variable for the research question pertained to success rates in the subsequent gateway mathematics course (i.e., pass with a C or better). The independent variable pertained to the type of DE course completed (i.e., 16-weeks or 4-weeks).

The participants were students at 12 community colleges in the NCCCS, with multiple colleges represented. Small, large, rural, urban, eastern, central, and western North Carolina colleges were all represented in this study, and permission was obtained from the appropriate Institutional Review Board (IRB) and the 12 participating colleges as well as the NCCCS Office. This study used archival data from the NCCCS data warehouse. Computation of the data calculated the subsequent course success rates for students prior to and after the redesign. Subsequent gateway credit-bearing course success rates were computed for all DE mathematics students (at each institution) who completed a DE mathematics course and then enrolled in a gateway credit-bearing course within the same or next academic year at the same institution. A C or higher in the gateway course is considered success. Data from 2010-11 established the subsequent course success rate for former DE mathematics students in the 16-week course format who attempted their gateway course during the same or next academic year at the same college. Data from 2013-14 established the subsequent course success rate for former DE mathematics students in the 4-week DE mathematics course format who attempted their gateway course during the same or next academic year at the same college.

A weighted chi-square test with contingency tables analyzed the data (Field, 2013; Johnson \& Christensen, 2012). An excel file from the system office contained the total number of $A, B, C, D, F, O W$ (official withdraw), and $W$ (withdraw) grades. Each college had different guidelines for the use of each of those withdraws. Passing grades were the total of $A, B$, and $C$ grades, and failing grades were the total of $D, F, O W$, and $W$ grades. These totals, the weighted cases (Field, 2013), were analyzed in SPSS version 24.

Descriptive statistics addressed the research question. A $2 \times 2$ contingency table answered the research question. The rows represented the number of students in 16-week and 4-week DE mathematics courses, and the columns represented the number of students who passed or failed the subsequent gateway mathematics course. The chi-square associations test determined if any statistically significant relationships occurred in all comparisons (Johnson \& Christensen, 2012). The level of significance for the test was set at $p<0.05$. 


\section{Results}

A total of $4,616 \mathrm{DE}$ mathematics students from the predesign courses in 2010-11 took a gateway course during the designated parameters of the study at the 12 participating colleges. 2,905 of the students passed the gateway course, resulting in a $62.93 \%$ course success rate. During the redesign year of 2013-14, a total of 3,486 students took the DE and gateway courses in the designated time frame, and 2,192 of them passed the gateway course, resulting in a $62.88 \%$ success rate (see Table 1 ). The comparison of these two course-sequence structures did not result in a statistically significant relationship (X2(1) $=0.002, p=0.961$ ) (see Table 2 ). Therefore, no difference exists between subsequent success rates for students who took the 16-week course sequence versus the accelerated 4-week course sequence. Acceleration of the material and less time allotted for each course did not affect students who completed their DE mathematics courses and then took the corresponding gateway credit-bearing mathematics course in the same or subsequent academic school year.

Table 1

Pre- and Post-Redesign Comparison

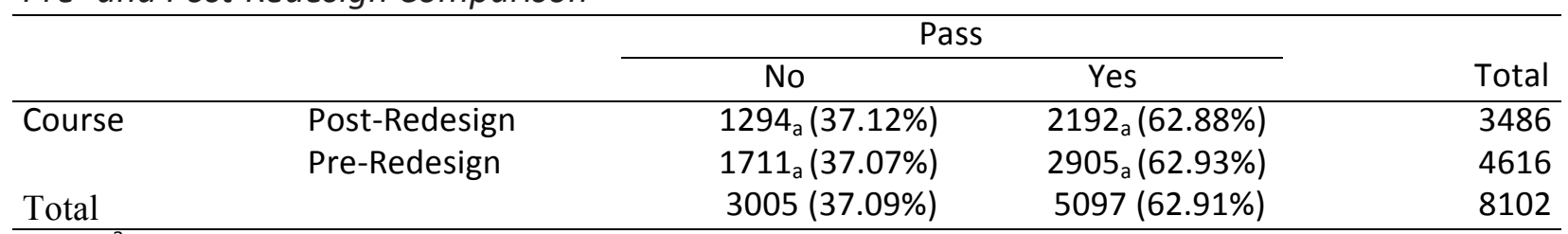

Note: ${ }^{a}$ Subset of pass categories whose column proportions do not differ significantly from each other at the .05 level.

Table 2

Chi-Square Test for Pre- and Post-Redesian

\begin{tabular}{|c|c|c|c|c|c|}
\hline & Value & $d f$ & $\begin{array}{l}\text { Asymptotic } p \\
\text { (2-sided) }\end{array}$ & $\begin{array}{c}\text { Exact } p \\
\text { (2-sided) }\end{array}$ & $\begin{array}{l}\text { Exact } p \\
\text { (1-sided) }\end{array}$ \\
\hline Pearson Chi-Square $^{a}$ & .002 & 1 & .961 & & \\
\hline Continuity Correction $^{\mathrm{b}}$ & .001 & 1 & .979 & & \\
\hline Likelihood Ratio & .002 & 1 & .961 & & \\
\hline Fisher's Exact Test & & & & .963 & .490 \\
\hline$N$ of Valid Cases & 8102 & & & & \\
\hline
\end{tabular}

Note:a. 0 cells $(0.0 \%)$ have expected count less than 5 . The minimum expected count is 1292.94 .

b. Computed only for a $2 \times 2$ table 


\section{Discussion}

The results from this study suggest that accelerating the curriculum did not affect the subsequent course success rates but rather shortened the amount of time for many students to complete the DE mathematics sequence. The FastStart Program at the Community College of Denver completed complementary research showing that acceleration did not negatively affect subsequent course success (Edgecombe, Jaggars, Baker, \& Bailey, 2013; Jaggars, Hodara, et al., 2014). Similar to this study, a study of four accelerated models by the Community College Research Center addressed concerns that accelerated courses would result in a lower success rate reported similar findings (Jaggars, Edgecombe et al., 2014). Results of studies presented by Edgecombe (2011) show that a change of structure alone resulted in increased student success "even when teaching practice remains unchanged" (p. 25). However, Edgecombe (2011) did suggest that most structural changes are accompanied by a pedagogical change, but more research on the outcomes using different instructional designs is needed.

One strategy that can help facilitate the success of acceleration is teaching mathematics conceptually so that students can use reason to solve problems rather than trying to memorize multiple procedures (Stigler et al., 2010). Stigler et al. evaluated placement-test scores and analyzed the worked solutions of mathematics questions that were solved by 748 community college DE mathematics students so that the researchers could evaluate the reasoning skills used by students when solving problems. After administering the mathematics questions to students, Stigler et al. (2010) identified the most difficult placement-test questions. In review of the errors, Stigler et al. (2010) began to draw the conclusion "that rather than using number sense, students rely on memorized procedure, only to carry out the procedure incorrectly or inappropriately" (p. 9), and that the errors "may provide evidence that students have a disposition to treat the goal of mathematical problems as getting answers quickly rather than correctly and with understanding" (p. 9). The focus of solving a problem was on a procedure rather than on numerical logic and reasoning, and with any reasoning, many of the errors could have been avoided. Stigler et al. (2010) also suggested that the difference in the level of conceptual understanding between students who tested into basic arithmetic versus elementary algebra may not be that different. Opportunities need to be presented that give students the skills to conceptually understand mathematics and the time to practice it (Stigler et al., 2010). Without reasoning, students rely on multiple procedures that they have memorized and often confuse when using the procedures together.

\section{Limitations}

Because of the relative new implementation of the redesigned DE mathematics courses, this study had some limitations. At the time of the study, clean data was only available for one year of implementation. As stated earlier, studies with longer time frames are needed. Conducting this study again with multiple years of data would be helpful in supporting the effect of the acceleration. Also, this study was conducted with only 12 of the 58 community colleges in North Carolina Community College System, and a study using all 58 may result in different statistics. Finally, this study was specific to North Carolina and it is possible that the results could not be generalizable to other colleges and states outside of North Carolina.

\section{Conclusion}

The conclusion of no statistically significant difference between the subsequent gateway course success rates in relation to the length of the course implies that length does not make a difference. Therefore, instructors should not fear acceleration of content into smaller units of time. Students were able to learn and remember the material at about the same rate whether they were in class for 16 weeks, learning multiple concepts during the semester, or four weeks, learning one concept at a time. There was no definitive answer to the common argument of whether more or less time is better in this study. Based on the findings of this study, if acceleration will help students complete faster, then it should be considered when redesigning DE mathematics sequence options. 
References

Ariovich, L., \& Walker, S. A. (2014). Assessing course redesign: The case of developmental math. Research and Practice in Assessment, 9, 4557.

Austin, A. M., \& Gustafson L. (2006). Impact of course length on student learning. Journal of Economics and Finance Education, 5(1), 26-37.

Barragan, M., \& Cormier. M. S. (2013). Enhancing rigor in developmental education. Inside Out, 1(4). Retrieved from http://ccrc.tc.columbia. edu/publications/enhancing-rigor-in-developmental-education.html

Boylan, H. R. (2011). Improving success in developmental mathematics: An interview with Paul Nolting. Journal of Developmental Education, 34(3), 20-22, 24, 26.

Community College Research Council. (2012). Doing developmental education differently. Inside Out, 1(1). Retrieved from http://ccrc.tc.columbia.edu/publications/doing-developmental-education-differently.html

Edgecombe, N. (2011, February). Accelerating the academic achievement of students referred to developmental education (CCRC Working Paper no. 30). CCRC, Teacher's College Columbia University,. Retrieved from http:// ccrc.tc.columbia.edu/publications/accelerating-academic-achievement-developmental-education.html

Edgecombe, N., Jaggars, S. S., Baker, E. D., \& Bailey, T. (2013, February). Acceleration through a holistic support model: An implementation and outcomes analysis of FastStart@CCD. CCRC, Teacher's College, Columbia University. Retrieved from http://ccrc.tc.columbia. edu/publications/acceleration-through-holistic-support-model.html

Field, A. (2013). Discovering statistics using SPSS statistics. Thousand Oaks, CA: SAGE.

Guskey, T. R. (2001, April). Benjamin S. Bloom's contributions to curriculum, instruction, and school learning. Paper presented at the meeting of the American Educational Research Association, Seattle, WA. Retrieved from ERIC database. (ED457185)

Guy, G. M., Cormick, J., Holt, R. J., \& Russell, A. S. H. (2015). Accelerated developmental arithmetic using problem solving. Journal of Developmental Education, 39(1), 2-8.

Haywood, C., \& Willett, T. (2014, April). Curricular redesign and gatekeeper completion: $A$ multi-college evaluation of the California Acceleration Project. Retrieved from http:// www.rpgroup.org/projects/cap.
Jaggars, S. S., Edgecombe, N., \& Stacey, G. W. (2014). What we know about accelerated developmental education. CCRC, Teacher's College, Columbia University. Retrieved from http:// ccrc.tc.columbia.edu/media/k2/attachments/accelerated-developmental-education.pdf

Jaggars, S. S., \& Hodara, M. (2011, November). The opposing forces that shape developmental education: Assessment, placement, and progression at CUNY community colleges. (CCRC Working Paper no. 36). CCRC, Teacher's College, Columbia University. Retrieved from http://ccrc.tc.columbia.edu/publications/opposing-forces-developmental-education.html

Jaggars, S. S., Hodara, M., Cho, S., \& Xu, D. (2014). Three accelerated developmental education programs: Features, student outcomes, and implications. Community College Review, 1-24. doi:10.1177/0091552114551752

Johnson, B., \& Christensen, B. (2012). Educational research: Qualitative, quantitative, and mixed approaches (4th ed.). Thousand Oaks, CA: SAGE.

McTiernan, L., Palmer, I., \& Fulton, M. (2013, May). NextDev challenge: Statewide remedial education redesign. Retrieved from http://www. ecs.org/clearinghouse/01/07/90/10790.pdf

Nodine, T., Dadgar, M., Venezia, A., \& Bracco, K. R. (2013). Acceleration in developmental education: Game changers series. San Francisco, CA: WestEd. Retrieved from http://www.wested. org/resources/acceleration-in-developmental-education-game-changers-series/

North Carolina Community College System. (2011a, February). Rethinking developmental math in North Carolina (DEl Update). Raleigh, NC. Retrieved from www.successnc.org/sites/default/files/dei_update_2011.pdf

North Carolina Community College System. (2011b, December). Developmental math modular curriculum: Module outlines and notes. Raleigh, NC. Retrieved from http://www. successnc.org/sites/default/files/inititiative-docs/Final2012\%20NCCCS\%20DevelopmentalMathModules.pdf

North Carolina Community College System. (2013). Success NC: North Carolina Community Colleges final report. Retrieved from http://www. successnc.org/successnc2013finalreport

Stigler, J. W., Givvin, K. B., \& Thompson, B. J. (2010). What community college developmental students understand about mathematics. MathAMAYTC Educator 1(3), 4-16. 